\title{
Murine Cytotoxic Activated Macrophages Inhibit Aconitase in Tumor Cells Inhibition Involves the Iron-Sulfur Prosthetic Group and Is Reversible
}

\author{
Jean-Claude Drapier and John B. Hibbs, Jr. \\ Veterans Administration Medical Center and Department of Medicine, Division of Infectious Diseases, \\ University of Utah School of Medicine, Salt Lake City, Utah 84148
}

\begin{abstract}
Previous studies show that cytotoxic activated macrophages cause inhibition of DNA synthesis, inhibition of mitochondrial respiration, and loss of intracellular iron from tumor cells. Here we examine aconitase, a citric acid cycle enzyme with a catalytically active iron-sulfur cluster, to determine if iron-sulfur clusters are targets for activated macrophage-induced iron removal. Results show that aconitase activity declines dramatically in target cells after $4 \mathrm{~h}$ of co-cultivation with activated macrophages. Aconitase inhibition occurs simultaneously with arrest of DNA synthesis, another early activated macrophage-induced metabolic change in target cells. Dithionite partially prevents activated macrophage induced aconitase inhibition. Furthermore, incubation of injured target cells in medium supplemented with ferrous ion plus a reducing agent causes near-complete reconstitution of aconitase activity. The results show that removal of a labile iron atom from the [4Fe-4S] cluster, by a cytotoxic activated macrophage-mediated mechanism, is causally related to aconitase inhibition.
\end{abstract}

\section{Introduction}

Mouse peritoneal macrophages activated in vivo by intracellular pathogens such as Mycobacterium bovis, strain BCG, or in vitro by lymphokines or by gamma interferon are cytotoxic for tumor target cells by a nonphagocytic mechanism (1-5). Mouse L1210 leukemia cells and guinea pig L10 hepatoma cells remain viable but develop inhibition of DNA synthesis, inhibition of mitochondrial respiration, and prolonged cytostasis during co-cultivation with cytotoxic activated macrophages (6). Granger and Lehninger (7) identified the sites of inhibition of mitochondrial respiration in cytotoxic activated macrophage-injured L1210 cells permeabilized with digitonin. They found that cytotoxic activated macrophages directly affected the electron transport chain in L1210 target cells. NADH:ubiquinone oxidoreductase (complex I) ${ }^{1}$ and succinate:ubiquinone oxidoreductase (complex

Address correspondence to Dr. Hibbs, Veterans Administration Medical Center (151G), 500 Foothill Drive, Salt Lake City, UT 84148.

Received for publication 3 February 1986.

1. Abbreviations used in this paper: Complex I, NADH:ubiquinone oxidoreductase; complex II, succinate:ubiquinone oxidoreductase; complex III, ubiquinol:ferricytochrome C oxidoreductase; complex IV, ferricytochrome C:oxygen oxidoreductase; DME, Dulbecco's modified Eagle's medium; FBS, fetal bovine serum; LPS, lipopolysaccharide; TMPD, tetramethylphenylenediamine.

J. Clin. Invest.

(c) The American Society for Clinical Investigation, Inc.

0021-9738/86/09/0790/08 $\$ 1.00$

Volume 78, September 1986, 790-797
II), the proximal reductases in the mitochondrial electron transport system, were markedly inhibited in injured L1210 cells. Furthermore, they found that cytotoxic activated macrophageinduced inhibition of mitochondrial respiration was selective since electron flow in more distal portions of the electron transport system remained intact. We recently observed that cytotoxic activated macrophages induce loss of iron-59 from prelabeled L1210 and L10 target cells (8). This finding raised the possibility that iron loss from cytotoxic activated macrophage injured target cells resulted in inhibition of certain enzymes that required iron for catalytic activity. Iron-sulfur clusters could be a site of iron loss. Inactivation of enzymes with iron-sulfur clusters could explain, at least in part, the pattern of metabolic inhibition observed in target cells of cytotoxic activated macrophages. It is of interest that complex I and complex II contain catalytically active ironsulfur clusters (9). This raised the possibility that aconitase, a citric acid cycle enzyme that catalyzes the isomerization of citrate to isocitrate via the intermediate cis-aconitate, could also be inhibited in injured L10 cells. Aconitase, although not catalyzing a redox reaction, contains a $[4 \mathrm{Fe}-4 \mathrm{~S}]$ cluster (10). In the experiments reported here, we examined mitochondrial aconitase activity in L10 and L1210 cells that had been co-cultivated with cytotoxic activated macrophages. Our results show that cytotoxic activated macrophages cause rapid inhibition of aconitase in these target cells ${ }^{2}$. In addition, we show that cytotoxic activated macrophage-induced inhibition of aconitase is due to loss of iron from the iron-sulfur cluster.

\section{Methods}

Materials. ADP, rotenone, antimycin A, oligomycin, tetramethylphenylenediamine (TMPD), isocitrate, $\alpha$-glycerol phosphate, cis-aconitate, L-cysteine, cycloheximide, tartronate, succinate, lipopolysaccharide (LPS; phenol extracted Escherichia coli serotype 0128:B12), and fatty acid free bovine serum albumin (BSA) were obtained from Sigma Chemical Co. (St. Louis, MO). Citrate was from Pfizer (New York, NY) or Matheson, Coleman, and Bell (Norwood, OH). Digitonin (Sigma Chemical Co.) was purified according to the method of Kun et al. (11) and a 5\% stock solution was prepared in dimethylsulfoxide. Sodium dithionite was purchased from Matheson, Coleman, and Bell and sodium thiosulfate was obtained from Mallinckrodt (St. Louis, MO). Components used to prepare tissue culture medium were from Gibco (Grand Island, NY). Calf serum and fetal bovine serum (FBS) were obtained from HyClone Laboratories, Inc. (Logan, UT). All other chemicals were reagent-grade and were purchased from commercial sources.

Macrophage effector cells. $\mathrm{C}_{3} \mathrm{H} / \mathrm{HeN}$ female or male mice were obtained from the Frederick Cancer Research Center Animal Facility (Frederick, MD). To obtain activated macrophages, we infected mice intraperitoneally with $5 \times 10^{6}-1 \times 10^{7}$ colony forming units of $M$. bovis,

2. The term inhibition is used in this manuscript to describe loss of aconitase activity in tumor target cells caused by a cytotoxic activated macrophage mediated effect on a cofactor for enzyme activity, the ironsulfur prosthetic group. 
Pasteur strain BCG (TMC/011); originally obtained from the Trudeau Institute, Saranac Lake, NY), 17-22 d before harvest and we inoculated them with $1 \mathrm{ml} \mathrm{10 \%}$ peptone (Difco Laboratories, Inc., Detroit, MI) 3$5 \mathrm{~d}$ before cells were harvested. Treatment of these in vivo activated macrophages with small amounts of LPS ( $20 \mathrm{ng} / \mathrm{ml}$ or less) after they are removed from the peritoneal cavity induces them to become cytotoxic for tumor cells (cytotoxic activated macrophages) (12). Stimulated macrophages were obtained from normal mice that were inoculated with 1 $\mathrm{ml}$ thioglycolate broth (Difco Laboratories, Inc.) or $1 \mathrm{ml} \mathrm{10 \%} \mathrm{peptone}$ 3-5 d before harvest. Stimulated macrophages do not become cytotoxic for tumor cells when treated with small amounts of LPS in vitro (12).

Culture medium. DME was supplemented with $20 \mathrm{mM}$ Hepes, 100 $\mathrm{U} / \mathrm{ml}$ penicillin, and $100 \mu \mathrm{g} / \mathrm{ml}$ streptomycin (referred to as Dulbecco's modified Eagle's medium, DME). DME for the continuous cultivation of target cells contained $5.6 \mathrm{mM}$ glucose and DME used for the cocultivation contained $17.6 \mathrm{mM}$ glucose.

Target cells. The methylcholanthrene-induced murine (DBA/2) lymphoblastic leukemia cell line (L1210) and the diethyl-nitrosamineinduced guinea pig (strain 2) hepatoma cell line (L10) were maintained in spinner suspension culture in DME plus 5\% FBS (L1210) or 5\% calf serum (L10). L1210 cells and L10 cells were tested periodically using the Mycotrin-TC mycoplasm test system (New England Nuclear, Boston, MA) and have been consistently negative for mycoplasm contamination.

Macrophage-tumor cell cocultures. Activated or stimulated macrophage monolayers were prepared by adding peritoneal exudate cells ( 1.5 $\times 10^{6} / \mathrm{cm}^{2}$ ) to 80-mm diameter tissue culture dishes (Costar 3100; Costar, Cambridge, MA) in DME and adhered for $60-90$ min at $37^{\circ} \mathrm{C}$ in a $5 \%$ $\mathrm{CO}_{2}$ atmosphere. Nonadherent peritoneal exudate cells were then removed by washing three times with phosphate-buffered saline (PBS). Log phase $\mathrm{L} 10$ cells $\left(1.2 \times 10^{5} / \mathrm{cm}^{2}\right)$ or L1210 cells $\left(2.4 \times 10^{5} / \mathrm{cm}^{2}\right)$ were added to the activated macrophage monolayers in DME $+20 \mathrm{ng} / \mathrm{ml}$ LPS with 5\% FBS (L1210) or 5\% calf serum (L10).

Respiration measurements. Oxygen consumption was measured with a Clark oxygen electrode (model 53; Yellow Springs Instrument Co., Yellow Springs, $\mathrm{OH}$ ). Tumor target cells were removed from the macrophage monolayers and permeabilized with $0.007 \%$ digitonin in respiration medium ( $0.25 \mathrm{M}$ sucrose, $20 \mathrm{mM}$ Hepes, pH 7.2, $2 \mathrm{mM} \mathrm{Pi,} 10$ $\mathrm{mM} \mathrm{MgCl}_{2}$, and $1 \mathrm{mM}$ EGTA) as previously described (7). Digitonin treatment selectively permeabilizes the plasma membrane while not affecting mitochondrial function (13). This permits access of mitochondrial substrates into the cell interior. Permeabilized cells were washed by centrifugation ( $180 \mathrm{~g}$ for $5 \mathrm{~min}$ ) to eliminate endogenous substrates and to permit added substrates to initiate respiration. To determine the effectiveness of the permeabilization procedure, cells were counted in the presence of trypan blue (cells do not exclude trypan blue after successful permeabilization). Measurement of L1210 respiration was initiated by adding permeabilized L1210 cells to respiratory medium supplemented with $1 \mathrm{mM} \mathrm{ADP}$ and appropriate respiratory substrate as described (7). However, for measurement of L10 cell respiration, cells were incubated in respiratory medium containing appropriate respiratory substrate before initiating state 3 respiration rate by adding $1 \mathrm{mM}$ ADP. For both cell lines, the respiration medium was supplemented with $0.7 \%$ fatty acidfree BSA during measurement of $\mathrm{O}_{2}$ consumption. When citrate or isocitrate-dependent respiration was measured in L10 cells, $5 \mathrm{mM}$ tartronate (2-hydroxy malonate) was added to the respiration medium as an exchange partner for the tricarboxylate-transporter, which facilitates the entry of citrate and isocitrate into the mitochondrial matrix $(14,15)$. Tartronate was not needed for entry of citrate or isocitrate into the mitochondria of L1210 cells. Under these experimental conditions, the respiratory control ratio of control L10 cells or L1210 cells was usually $>5$ using succinate as substrate (state 3 rate [substrate $+1 \mathrm{mM}$ ADP] and state 4 rate [substrate $+1 \mathrm{mM}$ ADP $+100 \mathrm{nM}$ oligomycin]). The oxygen concentration in the air-saturated respiration medium was taken as $390 \mathrm{ng}$ atoms $/ \mathrm{ml}$.

Spectrophotometric measurement of aconitase and isocitrate dehydrogenase. Disappearance of cis-aconitate at $240 \mathrm{~nm}$ was measured with a Cary $16 \mathrm{~S}$ recording spectrophotometer (Variant Instruments, Palo Alto, CA) by a modification of a previously described method (16). Cells were permeabilized with $0.007 \%$ digitonin as described above to remove cytoplasmic proteins and then lysed with $0.2 \%$ Triton X-100 in $0.15 \mathrm{M}$ $\mathrm{NaCl}$ buffered with $30 \mathrm{mM}$ triethanolamine- $\mathrm{HCl}, \mathrm{pH} 7.2$. Lysate was centrifuged $(5,000 \mathrm{~g}$ for $15 \mathrm{~min})$ and the supernatant was immediately assayed for aconitase activity at $25^{\circ} \mathrm{C}$ in the presence of $0.02 \% \mathrm{BSA}$. The reaction was started with the addition of $0.2 \mathrm{mM}$ cis-aconitate and enzyme activity was determined from the initial reaction rate. An extinction coefficient of $3.41 \mathrm{~cm}^{-1} \mathrm{mM}^{-1}$ was used for cis-aconitate (17). Isocitrate dehydrogenase was measured spectrophotometrically in the lysates by following the reduction of $\mathrm{NADP}^{+}$with isocitrate as substrate. Isocitrate ( $1 \mathrm{mM}$ final concentration) was added to the lysates to start the reaction and the coupled reduction of $\operatorname{NADP}^{+}(0.1 \mathrm{mM})$ was followed at 340 $\mathrm{nm}$. Reaction was performed at $37^{\circ} \mathrm{C}$ in a buffer, $\mathrm{pH} 7.2$, containing 30 $\mathrm{mM}$ triethanolamine- $\mathrm{HCl}, 0.15 \mathrm{M} \mathrm{NaCl}$, and $10 \mathrm{mM} \mathrm{MgCl}_{2}$.

Measurement of DNA synthesis and target cell viability. Determination of $\left[{ }^{3} \mathrm{H}\right]$ thymidine uptake as well as viability of $\mathrm{L} 10$ and $\mathrm{L} 1210$ cells was as previously described $(8,18)$.

Measurement of protein synthesis. L10 cells cultivated with cycloheximide for various intervals of time were washed by centrifugation ( $180 \mathrm{~g}$ for $5 \mathrm{~min}$ ) and counted. Aliquots, in duplicate ( $10^{5} \mathrm{~L} 10$ cells), were pulse-labeled with $2 \mu \mathrm{Ci} / \mathrm{ml}$ of $\mathrm{L}-\left[{ }^{3} \mathrm{H}\right]$ leucine in $\mathrm{DME}+5 \%$ calf serum. Incorporated radioactivity was measured as previously described (8).

Protein determination. Protein content of cell lysates was determined using the Bio-Rad protein assay kit (Bio-Rad Laboratories, Richmond, CA) and with BSA as a standard (19).

Statistical analysis. Statistical analysis of data was by Student's $t$ test.

\section{Results}

Polarographic measurement of aconitase, complex I, and complex II activity in L10 cells co-cultivated with cytotoxic activated macrophages. In Fig. 1, a simplified diagram of the citric acid cycle and the electron transport system is outlined for reference. Aconitase activity as well as different segments of the electron transport chain can be measured in situ using polarographic technique in the same sample of digitonin-treated cells. Fig. 2 shows the oxygen electrode trace of L10 cells cultured alone $(A)$ or co-cultivated with cytotoxic activated macrophages $(B)$. Citrate-dependent respiration in the presence of ADP (state 3 respiration) was strongly inhibited in L10 cells that had been cocultivated with cytotoxic activated macrophages for $7 \mathrm{~h}$. Addition of isocitrate resulted in resumption of $\mathrm{O}_{2}$ uptake, showing that
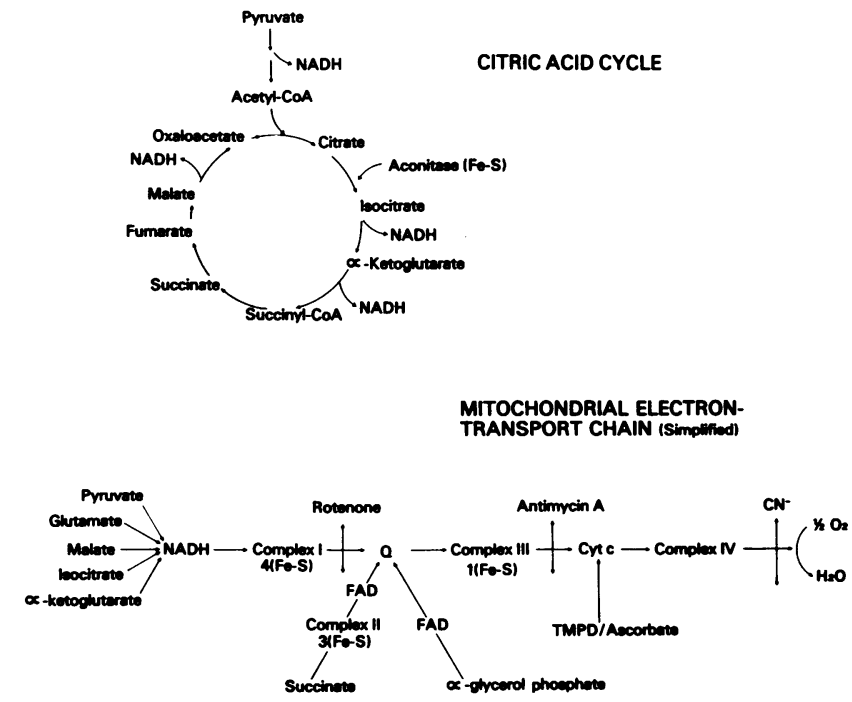

Figure 1. Schematic representation of the citric acid cycle and the mitochondrial electron transport chain. 


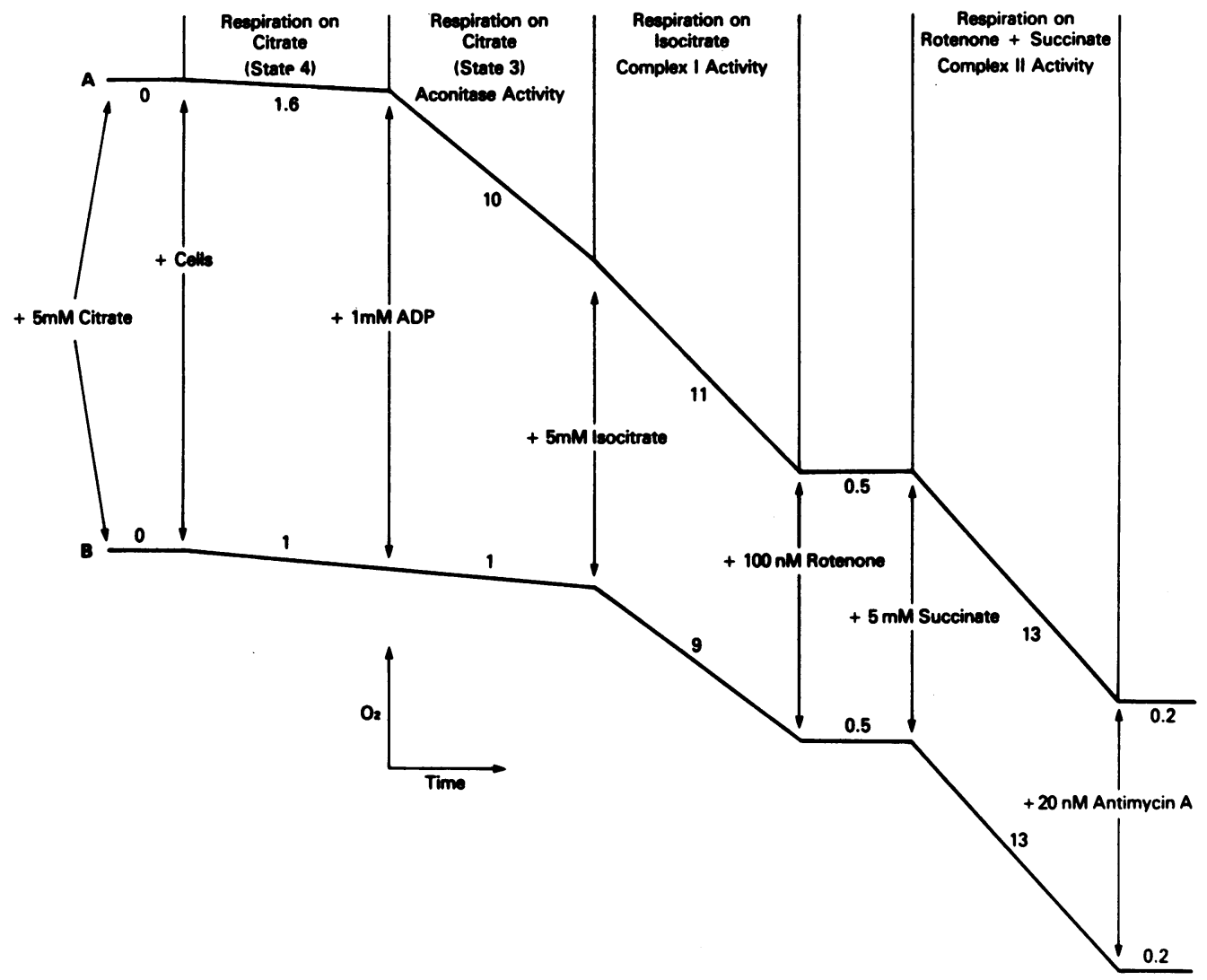

Figure 2. Comparison of citrate, isocitrate, and succinate plus rotenone oxidation in control L10 cells $(A)$ and in L10 cells co-cultivated for $7 \mathrm{~h}$ with cytotoxic activated macrophages $(B)$. L10 cells (5 $\left.\times 10^{6}\right)$ were permeabilized with $0.007 \%$ digitonin and washed by centrifugation $(180 \mathrm{~g})$ to remove endogenous substrate. Cells were resuspended in $2.8 \mathrm{ml}$ respiration medium and $\mathrm{O}_{2}$ consumption was measured in a magnetic stirred thermostated chamber with a Clark oxygen electrode. The numbers are rates of oxygen consumption in $\mathrm{ng}$ atoms $\mathrm{O} \cdot \mathrm{min}^{-1} \cdot 10^{-6}$ L10 cells. Antimycin A, an inhibitor of mitochondrial respiration (see Fig. 1), inhibited $\mathrm{O}_{2}$ consumption by both co-cultivated $\mathrm{L} 10$ cells and control L10 cells. This demonstrates that the $\mathrm{O}_{2}$ consumption measured was of mitochondrial origin.

the citric acid cycle enzyme isocitrate dehydrogenase as well as complex I, ubiquinol:ferricytochrome C oxidoreductase (complex III), and ferricytochrome C:oxygen oxidoreductase (complex IV) of the electron transport chain were intact at this relatively early time during the co-cultivation period. Complex II activity, as assessed by oxidation of succinate in the presence of rotenone, was unimpaired after $7 \mathrm{~h}$ of co-cultivation of L10 cells with cytotoxic activated macrophages. This pattern of results, inhibition of citrate oxidation but near normal oxidation of isocitrate (complex I) and normal oxidation of succinate plus rotenone (complex II), suggests that cytotoxic activated macrophage mediated inhibition of the isomerization of citrate to isocitrate catalyzed by aconitase occurs before inhibition of complex I and complex II.

Kinetics of inhibition of aconitase, complex I, and complex II activity in L10 cells co-cultivated with cytotoxic activated macrophages. Fig. 3 shows that citrate-dependent respiration in L10 cells is significantly depressed after $4 \mathrm{~h}$ of co-cultivation and is undetectable after $8 \mathrm{~h}$ of co-cultivation. At this time, isocitrate (complex I), is still an effective substrate but respiration supported by isocitrate slowly declines versus time and is reduced more than $80 \%$ after $22 \mathrm{~h}$ of co-cultivation. Complex II activity, oxidation of succinate in the presence of rotenone, declines even more gradually than complex I activity in L10 target cells and is reduced to $71 \%$ of control cells after $22 \mathrm{~h}$ of co-cultivation with cytotoxic activated macrophages.

The following evidence suggests that after 20-24 h of cocultivation of $\mathrm{L} 10$ cells with cytotoxic activated macrophages, the limiting steps for isocitrate and succinate plus rotenone oxidation are at the level of complex I and complex II, respectively: (a) The oxidation of other NADH-linked substrates (e.g., $5 \mathrm{mM}$ malate) is inhibited to the same extent as oxidation of isocitrate. (b) Isocitrate dehydrogenase was functionally intact in digitonin permeabilized L 10 cells. For example, after $20 \mathrm{~h}$ of co-cultivation, at a time when isocitrate-dependent respiration was $80 \%$ inhibited, isocitrate dehydrogenase activity in $\mathrm{L} 10$ cells co-cultivated with cytotoxic activated macrophages was $48 \mathrm{nM}^{-1} \mathrm{NDP}^{+}$reduced $\cdot \min ^{-1} \cdot \mathrm{mg}$ protein ${ }^{-1}$ while that of control cells was 35 nM NADP ${ }^{+}$reduced $\cdot \min ^{-1} \cdot \mathrm{mg}$ protein $^{-1}$. (c) Complex III and complex IV of the mitochondrial electron transport chain remain functionally intact in co-cultivated $\mathrm{L} 10$ cells. The rate of state

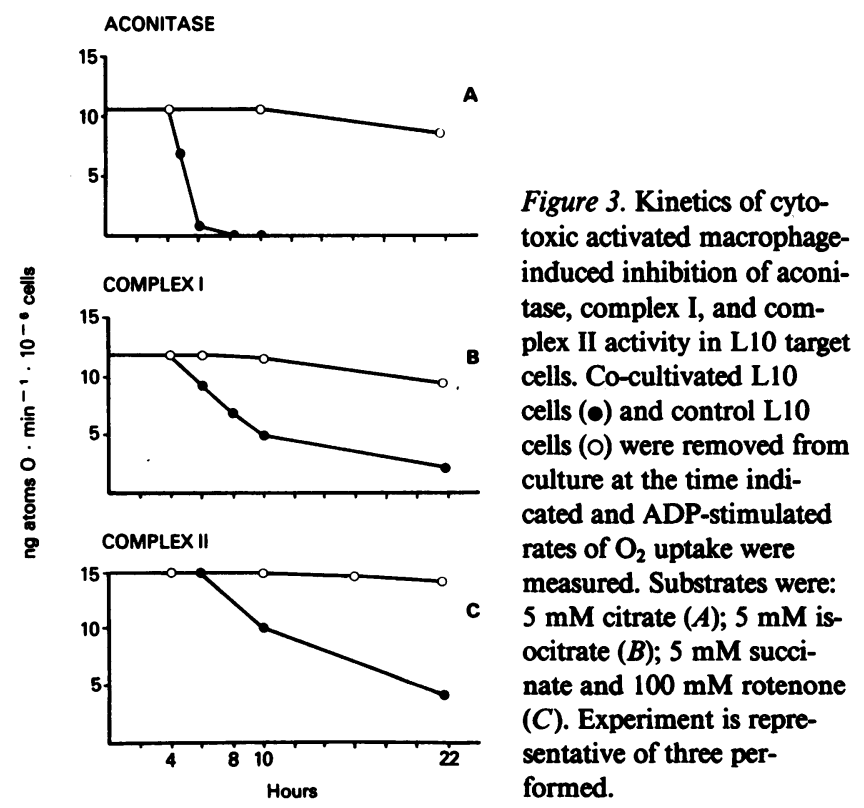




\begin{tabular}{lllll}
\hline & & \multicolumn{2}{l}{ Substrate and oxygen consumption } \\
\cline { 3 - 6 } L10 cells cultured with: & Experiments & $\begin{array}{l}\text { Citrate } \\
\text { (aconitase activity) }\end{array}$ & $\begin{array}{l}\text { lscitrate } \\
\text { (complex I activity) }\end{array}$ & $\begin{array}{c}\text { Succinate and rotenone } \\
\text { (complex II activity) }\end{array}$ \\
\hline Cultured alone (control L10 cells) & 26 & $9.3 \pm 2.2$ & $10.8 \pm 2.6$ & $13.2 \pm 2.5$ \\
Cytotoxic activated macrophages (BCG, activated) & 24 & $1.4 \pm 1.4^{*}$ & $7.2 \pm 1.8^{*}$ & $12.8 \pm 2.8$ \\
Stimulated macrophages (thioglycollate-elicited) & 4 & $(15 \%)$ & $(77 \%)$ & $(97 \%)$ \\
Stimulated macrophages (proteose-peptone-elicited) & 4 & $10.0 \pm 1.3$ & $11.5 \pm 1.2$ & $12.2 \pm 1.2$ \\
& & $9.8 \pm 0.3$ & $11.4 \pm 1.8$ & $14.8 \pm 0.6$ \\
\hline
\end{tabular}

L10 cells were cultured alone or co-cultivated with macrophages for $6.5 \mathrm{~h}$ before respiration measurements were made using digitonin-treated L10 cells. Concentration of substrates and inhibitor added to the respiration medium: aconitase activity, $5 \mathrm{mM}$ citrate; complex I activity, $5 \mathrm{mM}$ isocitrate; and complex II activity, $5 \mathrm{mM}$ succinate $+100 \mathrm{nM}$ rotenone. Data are presented as rates of substrate oxidation in $\mathrm{ng}$ atoms 0 $\mathrm{min}^{-1} \cdot 10^{-6} \mathrm{~L} 10$ cells. Values are the mean \pm SD for the number of experiments shown. Numbers in parentheses are percent of activity of control L10 cells.

$* P<0.001$ vs. control L10 cells.

3 oxidation of $\alpha$-glycerol phosphate by L10 cells that were cocultivated with cytotoxic activated macrophages for $22 \mathrm{~h}$ was $2.5 \mathrm{ng}$ atoms $0 \cdot \mathrm{min}^{-1} \cdot 10^{-6} \mathrm{~L} 10$ cells, which was identical to state 3 oxidation of $\alpha$-glycerol phosphate by control L10 cells. This shows that, as in co-cultivated L1210 cells (7), the respiratory chain between ubiquinone and $\mathrm{O}_{2}$ is functional in $\mathrm{L} 10$ cells after activated macrophage-induced injury. In addition, the terminal segment of the electron chain can support electron flow at high rates in injured L10 cells. The oxidation of $0.2 \mathrm{mM}$ TMPD plus $1 \mathrm{mM}$ ascorbate (in the presence of $100 \mathrm{nM}$ rotenone and $20 \mathrm{nM}$ antimycin A) was $25 \mathrm{ng}$ atoms $0 \cdot \mathrm{min}^{-1} \cdot 10^{-6} \mathrm{~L} 10$ cells co-cultivated with cytotoxic activated macrophages for 22 $\mathrm{h}$ and $30 \mathrm{ng}$ atoms $0 \cdot \mathrm{min}^{-1} \cdot 10^{-6}$ control L10 cells. Thus, the terminal part of the electron transport chain of injured L10 cells, like injured L1210 cells (7), can support electron flow above usual state 3 rates.

Measurement of aconitase, complex I, and complex II activity in L10 cells co-cultivated with stimulated macrophages. Stimulated macrophages elicited in normal mice by intraperitoneal injection of sterile nonimmunogenic inflammatory stimulants such as $10 \%$ proteose peptone broth or thioglycollate broth are not cytotoxic for tumor cells (12). Table I shows that citrate, isocitrate, or succinate plus rotenone oxidation was unchanged in $\mathrm{L} 10$ cells after $6.5 \mathrm{~h}$ of co-cultivation with stimulated macrophages (thioglycollate or proteose peptone-elicited macrophages). At this same time, citrate oxidation in L10 cells cocultivated with cytotoxic activated macrophages was only $15 \%$ and isocitrate oxidation was $67 \%$ of that measured in control L10 cells. Even after $20 \mathrm{~h}$ of co-cultivation of L10 cells with stimulated macrophages, there was no decrease in $\mathrm{O}_{2}$ consumption with citrate, isocitrate, or succinate plus rotenone as substrate when compared with control L10 cells (data not shown). These results show that co-cultivation of L10 cells with stimulated macrophages, unlike co-cultivation of L10 cells with cytotoxic activated macrophages, has no effect on aconitase activity or complex I and complex II of the mitochondrial electron transport chain.

Spectrophotometric measurement of aconitase activity. The above results show marked inhibition of citrate oxidation in the presence of significant isocitrate-dependent $\mathrm{O}_{2}$ consumption in L10 cells co-cultivated with cytotoxic activated macrophages for 6-7 h. This strongly suggests inhibition of aconitase activity is an early event in the development of activated macrophage- mediated cytotoxicity by $\mathrm{L} 10$ cells. It is unlikely that inhibition of citrate transport, but not isocitrate transport, into mitochondria explain the polarographic results obtained. However, to rule out this possibility, we also measured the enzymatic activity of aconitase by recording the aconitase-dependent change in ultraviolet absorbance of cis-aconitate in $\mathrm{L} 10$ cell lysates. The results of the spectrophotometric assay are in agreement with the polarographic results. Table II shows that aconitase activity present in lysates of L10 cells co-cultivated with cytotoxic activated macrophages for $6.5 \mathrm{~h}$ was only $14 \%$ of the activity present in lysates of control L10 cells. Thus, cytotoxic activated macrophage-mediated inhibition of aconitase activity in L10 target cells can be documented in two independent assays of enzymatic activity.

Comparison of citrate oxidation and $\left[{ }^{3} \mathrm{H}\right]$ thymidine uptake by L10 target cells. Fig. 4 shows the kinetics of inhibition of citrate oxidation and $\left[{ }^{3} \mathrm{H}\right]$ thymidine uptake in $\mathrm{L} 10$ target cells. The results show that inhibition of aconitase activity and inhibition of DNA synthesis in L10 cells co-cultivated with cytotoxic activated macrophages are early and simultaneous events.

Polarographic measurement of aconitase, complex I, and complex II activity in L1210 cells co-cultivated cytotoxic activated macrophages. To determine if aconitase activity is inhibited in another cell line, we examined the kinetics of inhibition of citrate, isocitrate, and succinate plus rotenone oxidation in mouse L1210 leukemia cells co-cultivated with cytotoxic activated macro-

Table II. Spectrophotometric Measurement of Aconitase Activity in L10 Cells Cultured Alone or with Macrophages

\begin{tabular}{llc}
\hline L10 cells cultured with: & Experiments & Aconitase activity \\
\hline Cultured alone (control L10 cells) & 5 & $39.0 \pm 6.9$ \\
$\begin{array}{l}\text { Cytotoxic activated macrophages } \\
\text { (BCG-activated) }\end{array}$ & 3 & $\begin{array}{c}5.4 \pm 1.0 \\
(14 \%)\end{array}$ \\
$\begin{array}{l}\text { Stimulated macrophages } \\
\text { (thioglycollate-elicited) }\end{array}$ & 3 & $41.3 \pm 7.3$ \\
\hline
\end{tabular}

L10 cells were cultured alone or co-cultivated with macrophages for $6.5 \mathrm{~h}$ before performance of the spectrophotometric assay. Results are expressed as rate of cis-aconitate disappearance in nanomoles per minute per $\mathrm{mg}$ protein. Values are the mean \pm SD for the number of experiments shown. Number in parentheses is the percent of activity of control L10 cells. 


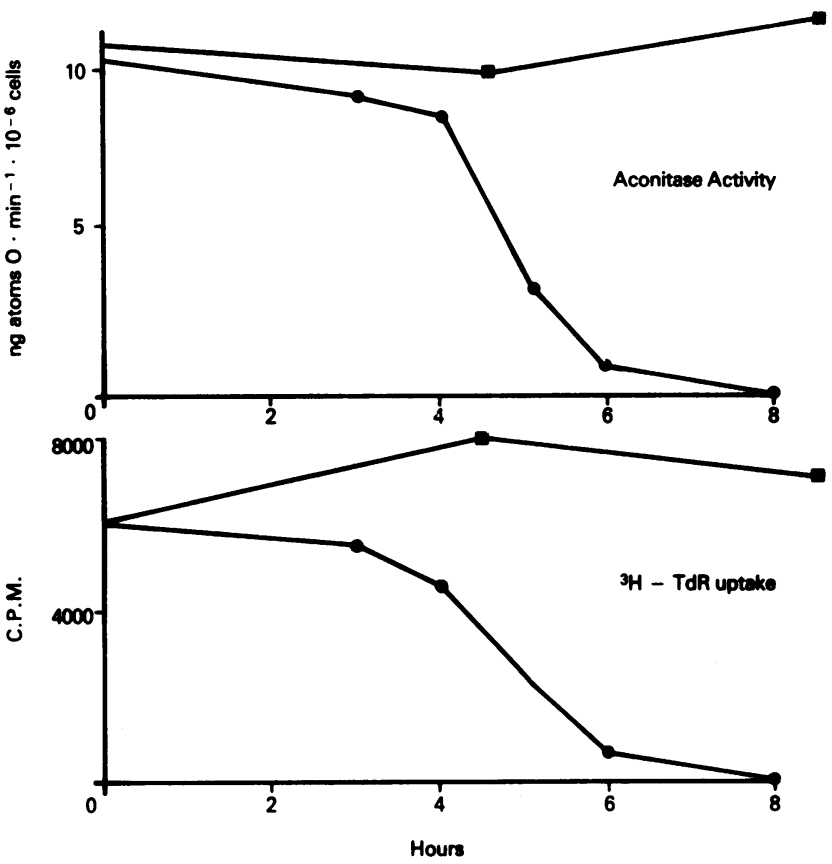

Figure 4. The kinetics of citrate-dependent respiration (aconitase activity) and $\left[{ }^{3} \mathrm{H}\right]$ thymidine incorporation into DNA in L10 cells cultured alone ( $\square$ ) or co-cultivated with cytotoxic activated macrophages (๑). Measurement of aconitase activity: L10 cells were removed from culture at the indicated times, washed by centrifugation $(180 \mathrm{~g})$, permeabilized with digitonin, and state 3 respiration was measured in medium with $5 \mathrm{mM}$ citrate. Measurement of DNA synthesis: aliquots of $\mathrm{L} 10$ cells were removed from the same cultures used as a source of cells for measurement of aconitase activity, washed by centrifugation $(180 \mathrm{~g})$, pulse-labeled in duplicate for $30 \mathrm{~min}$ with $0.5 \mu \mathrm{Ci} \mathrm{ml}^{-1}$ $\left[{ }^{3} \mathrm{H}\right]$ thymidine in DME plus $5 \%$ calf serum, and processed as described $(8,18)$.

phages. Similar to the results with $\mathrm{L} 10$ cells, citrate oxidation (aconitase activity) rapidly declined after $4 \mathrm{~h}$ of co-cultivation of L1210 cells with cytotoxic activated macrophages (Fig. 5). Isocitrate (complex I) and succinate plus rotenone (complex II) also gradually declined in co-cultivated L1210 cells, which confirms the findings of Granger and Lehninger (7). These results show that the same pattern of enzyme inhibition develops in L10 cells and L1210 cells during co-cultivation with cytotoxic activated macrophages.

Measurement of aconitase turnover. $\mathrm{L} 10$ cells were cultivated in the presence of cycloheximide to determine if decreased protein synthesis could explain the rapid inhibition of aconitase activity in co-cultivated cells. Table III shows that aconitase was $91 \%$ active after $10 \mathrm{~h}$ of cycloheximide treatment (a time when aconitase is completely inhibited in L10 cells co-cultivated with cytotoxic activated macrophages) and that its half-life was $20 \mathrm{~h}$ in the presence of cycloheximide. L10 cells treated with cycloheximide incorporated $\mathrm{L}-\left[{ }^{3} \mathrm{H}\right]$ leucine at 19,13 , and $10 \%$ of the rate of control L10 cells after 10, 20, and $40 \mathrm{~h}$, respectively (average of four experiments). Similar results were found with L1210 cells. This shows that inhibition of protein synthesis cannot explain the rapid inhibition of aconitase activity caused by cytotoxic activated macrophages.

Comparison of citrate-dependent respiration in digitonintreated and endogenous respiration in L10 cells co-cultivated with activated macrophages. To determine the consequences of inhibition of aconitase activity on mitochondrial respiration, we

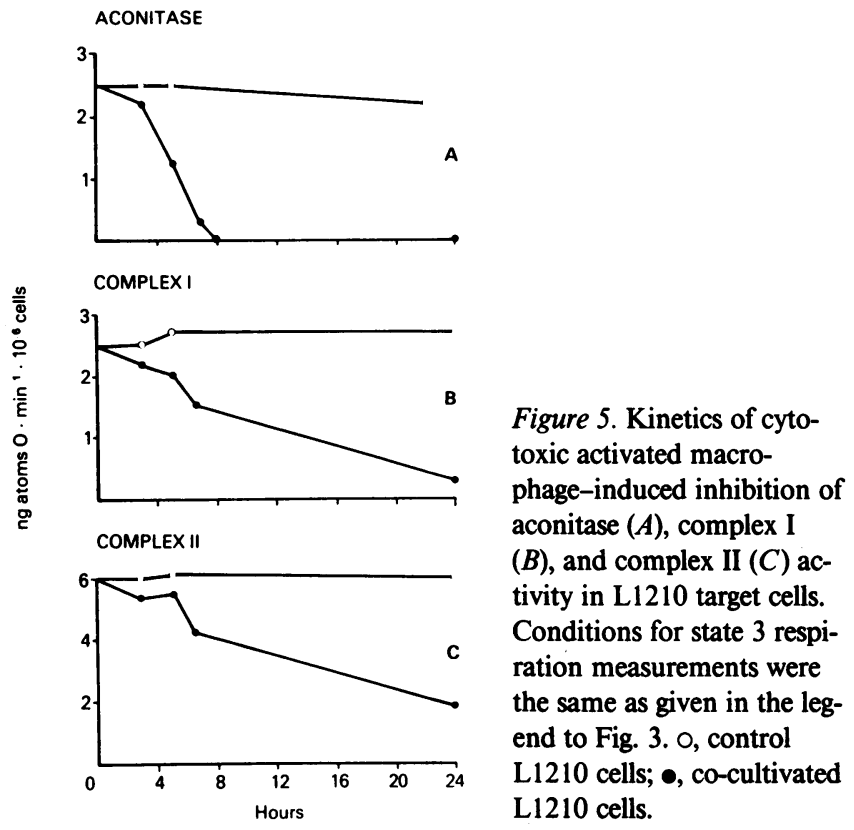

compared exogenous citrate-dependent respiration to endogenous respiration in intact L10 cells after $6 \mathrm{~h}$ of co-cultivation with cytotoxic activated macrophages. Oxidation of citrate by L10 cells that were co-cultivated with activated macrophages for $6 \mathrm{~h}$ was completely inhibited, while endogenous coupled and uncoupled respiration was unchanged from that measured in control L10 cells (Table IV). However, after $22 \mathrm{~h}$ of co-cultivation of L10 cells, both endogenous coupled and endogenous uncoupled respiration were markedly inhibited (Table IV). These results suggest that citric acid cycle block at the level of aconitase, which occurs relatively early during the cocultivation period does not inhibit mitochondrial respiration. Indeed, as long as complex I and complex II are still functional, endogenous substrates are able to circumvent the aconitase block.

Bypass of the aconitase reaction (and acetyl coenzyme A

Table III. Aconitase Activity in L10 Cells Treated with Cycloheximide to Inhibit Protein Synthesis

\begin{tabular}{llll}
\hline & \multicolumn{2}{l}{$\begin{array}{l}\text { Oxygen consumption (percent control L10 } \\
\text { cells) at various time intervals of cultivation } \\
\text { with cycloheximide }\end{array}$} \\
\cline { 2 - 4 } Substrates and inhibitor & $10 \mathrm{~h}$ & $20 \mathrm{~h}$ & $40 \mathrm{~h}$ \\
\hline & percent & percent & percent \\
Citrate (aconitase activity) & $91 \pm 9$ & $51 \pm 6$ & $39 \pm 5$ \\
$\begin{array}{l}\text { Isocitrate (complex I } \\
\text { activity) }\end{array}$ & $96 \pm 3$ & $60 \pm 15$ & $39 \pm 2$ \\
$\begin{array}{l}\text { Succinate + rotenone } \\
\text { (complex II activity) }\end{array}$ & $92 \pm 8$ & $70 \pm 13$ & $49 \pm 8$ \\
\hline
\end{tabular}

L10 cells were cultured with $10 \mu \mathrm{g} \mathrm{ml}^{-1}$ cycloheximide for the time interval indicated before state 3 respiration measurements were made using digitonin-treated $\mathrm{L} 10$ cells. Concentration of substrates and inhibitor added to the respiration medium: aconitase activity, $5 \mathrm{mM}$ citrate; complex I activity, $5 \mathrm{mM}$ isocitrate; and complex II activity, $5 \mathrm{mM}$ succinate $+100 \mathrm{nM}$ rotenone. $\mathrm{O}_{2}$ consumption was normalized to number of viable $\mathrm{L} 10$ cells and expressed as percent of control L10 cells not treated with cycloheximide. Values are mean \pm SD of four experiments. 
Table IV. Exogenous Citrate-dependent State 3 Respiration and Endogenous Respiration in Control L10 Cells and L10 Cells Co-cultivated with Cytotoxic Activated Macrophages

\begin{tabular}{|c|c|c|c|c|}
\hline & \multicolumn{4}{|c|}{ Oxygen consumption* } \\
\hline & \multicolumn{2}{|l|}{$6 \mathrm{~h}$} & \multicolumn{2}{|l|}{$22 \mathrm{~h}$} \\
\hline & $\begin{array}{l}\text { L10 } \\
\text { cells alone }\end{array}$ & $\begin{array}{l}\text { L10 cells } \\
\text { + cytotoxic } \\
\text { activated } \\
\text { macrophages }\end{array}$ & $\begin{array}{l}\text { L10 } \\
\text { cells alone }\end{array}$ & $\begin{array}{l}\text { L10 cells } \\
+ \text { cytotoxic } \\
\text { activated } \\
\text { macrophages }\end{array}$ \\
\hline $\begin{array}{l}\text { Citrate-dependent } \\
\text { respiration }\end{array}$ & 14 & 0 & N.D. $\ddagger$ & N.D. \\
\hline $\begin{array}{l}\text { Endogenous } \\
\text { respiration } \\
\quad+100 \mu \mathrm{M} 2,4\end{array}$ & 19 & 16 & 14 & 2 \\
\hline dinitrophenol & 26 & 24 & 33 & 2 \\
\hline
\end{tabular}

L10 cells were cultured alone or co-cultivated with cytotoxic activated macrophages for the time interval indicated before respiration measurements were made. $5 \mathrm{mM}$ citrate was present in the respiration medium for measurement of citrate-dependent $\mathrm{O}_{2}$ consumption in digitonin permeabilized L10 cells. Endogenous respiration was measured in parallel experiments in nonpermeabilized $\mathrm{L} 10$ cells in the presence or absence of 2,4 dinitrophenol.

* Units, ng atoms $\mathrm{O} \cdot \mathrm{min}^{-1} \cdot 10^{-6} \mathrm{~L} 10$ cells.

$¥$ N.D., not done.

(CoA) and citrate as respiratory substrates) could occur if glutamate, after transamination to the citric acid cycle intermediate $\alpha$-ketoglutarate, is utilized as an alternative respiratory substrate (see Fig. 1 for reference). The successive five reaction steps between $\alpha$-ketoglutarate and oxaloacetate could continue to function as a shortened pathway if oxaloacetate were transaminated to asparate. Asparate could be transported from mitochondria in exchange for its transamination partner glutamate. Glutamate, after transamination to $\alpha$-ketoglutarate, would be substrate for the first reaction in this shortened pathway. This possibility was examined in L10 cells that were co-cultivated with activated

Table V. Effect of Dithionite on Citrate

Oxidation (Aconitase Activity) in L10 Cells Co-cultivated with Cytotoxic Activated Macrophages

\begin{tabular}{lc}
\hline L10 cells cultured with: & $\begin{array}{l}\text { Oxygen } \\
\text { consumption* }\end{array}$ \\
\hline Cultured alone (control L10 cells) & $11.0 \pm 2.5$ \\
$\begin{array}{l}\text { Cytotoxic activated macrophages (BCG-activated) } \\
\text { Cytotoxic activated macrophages (BCG-activated) } \\
\quad+5 \mathrm{mM} \text { sodium dithionite }\end{array}$ & $2.3 \pm 1.7(79)$ \\
& $8.7 \pm 3.7(21) \ddagger$
\end{tabular}

L10 cells were cultured alone or co-cultivated with cytotoxic activated macrophages at $37^{\circ} \mathrm{C}$ in humidified $95 \%$ air, $5 \% \mathrm{CO}_{2}$ atmosphere for $6.5 \mathrm{~h}$ in the presence or absence of $5 \mathrm{mM}$ sodium dithionite, permeabilized with digitonin, and state 3 respiration was measured. Sodium dithionite had no effect on citrate oxidation in digitonin-permeabilized control L10 cells. Respiratory medium contained $5 \mathrm{mM}$ citrate during measurement of oxygen consumption. Values are the mean \pm SD of five experiments. Numbers in parentheses are percent inhibition. * Units, ng atoms $\mathrm{O} \cdot \mathrm{min}^{-1} \cdot 10^{-6} \mathrm{~L} 10$ cells.

$\ddagger$ Difference between groups co-cultivated in the presence or absence of sodium dithionite; $P<0.001$.
Table VI. Reconstitution of Citrate Oxidation (Aconitase Activity)

\begin{tabular}{lllc}
\hline $\begin{array}{l}\text { Additives present during 1-h second } \\
\text { incubation of L10 cells }\end{array}$ & Experiments & $\begin{array}{l}\text { Oxygen } \\
\text { consumption }\end{array}$ & $\begin{array}{l}\text { Percent } \\
\text { recovery* }\end{array}$ \\
\hline None & 6 & $0.9 \pm 0.9$ & 9 \\
$50 \mu \mathrm{M} \mathrm{FeSO}_{4}$ & 3 & $5.7 \pm 0.4$ & 59 \\
$1 \mathrm{mM} \mathrm{L}$-cysteine $_{50 \mu \mathrm{M} \mathrm{FeSO}_{4}+1 \mathrm{mM} \text { L-cysteine }}$ & 3 & $3.1 \pm 0.2$ & 32 \\
$3 \mathrm{mM}$ thiosulfate & 3 & $8.4 \pm 3.5$ & 87 \\
$50 \mu \mathrm{M} \mathrm{FeSO}_{4}+3 \mathrm{mM}$ thiosulfate & 3 & $1.8 \pm 0.9$ & 19 \\
& & $9.0 \pm 3.1$ & 94 \\
\hline
\end{tabular}

L10 cells were cultured alone or co-cultivated with cytotoxic activated macrophages for $6.5 \mathrm{~h}$. They were then removed from the macrophage monolayers, washed, and reincubated in a shaker (Lab-Line Instruments, Inc., Melrose Park, IL) (250 oscillations per minute) for $1 \mathrm{~h}$ at $37^{\circ} \mathrm{C}$ in DME plus $5 \%$ calf serum. The DME used for the 1-h second incubation was previously deaerated by saturation with $\mathrm{N}_{2}$ and contained no additives or the additives indicated below. State 3 respiration measurements were made after the 1-h second incubation using digitonin-treated $\mathrm{L} 10$ cells in respiration medium containing $5 \mathrm{mM}$ citrate. Citrate-dependent $\mathrm{O}_{2}$ consumption is presented as ng atoms $\mathrm{O} \cdot \mathrm{min}^{-1} \cdot 10^{-6} \mathrm{~L} 10$ cells. Values are the mean $\pm \mathrm{SD}$ for the number of experiments shown.

* Recovery is expressed as percent of citrate dependent respiration by control L10 cells $\left(9.6 \pm 1.1 \mathrm{ng}\right.$ atoms $\mathrm{O} \cdot \mathrm{min}^{-1} \cdot 10^{-6}$ cells, $\left.n=6\right)$.

macrophages for $7 \mathrm{~h}$ and then permeabilized with digitonin. In these cells, $5 \mathrm{mM}$ citrate no longer supported mitochondrial respiration but $5 \mathrm{mM} \alpha$-ketoglutarate was as effective as $5 \mathrm{mM}$ isocitrate as a respiratory substrate (both supported respiration at rates $80 \%$ of that measured in control $\mathrm{L} 10$ cells). These results show that endogenous respiration continues at a normal rate and that $\alpha$-ketoglutarate is an effective respiratory substrate in injured L10 cells at a time when aconitase activity is blocked but complex I and complex II are still functional.

Dithionite partially prevents inhibition of aconitase activity in L10 cells by activated macrophages. It is known that the enzymatic activity of aconitase is inactivated by mild oxidation $(20,21)$. Therefore, we supplemented the culture medium with reductants and measured aconitase activity in L 10 cells after 6.5 h of co-cultivation. $10 \mathrm{mM}$ L-cysteine or $5 \mathrm{mM}$ ascorbate had no consistent effect on aconitase inhibition (data not shown) but sodium dithionite partially prevented activated macrophageinduced inhibition of aconitase activity in L10 cells (Table V). These results suggest that dithionite or one of its products, e.g., thiosulfate, interfere with cytotoxic activated macrophage-mediated inhibition of aconitase activity in L10 target cells.

Reconstitution of aconitase activity. Early studies showed that ferrous ion and cysteine activate and stabilize highly purified aconitase preparations (22). Subsequent findings demonstrated that aconitase is reversibly inactivated by mild oxidative conditions $(20,21,23)$. Therefore, experiments were carried out to investigate whether ferrous ion alone, or ferrous ion in combination with cysteine or thiosulfate, could restore aconitase activity in L10 cells that previously had been co-cultivated with cytotoxic activated macrophages for $6.5 \mathrm{~h}$ (Table VI). A 1-h incubation of injured $\mathrm{L} 10$ cells in DME with $50 \mu \mathrm{M} \mathrm{FeSO}$ resulted in a restoration of aconitase activity to $59 \%$ of that in control L10 cells. When $1 \mathrm{mM}$ cysteine or $3 \mathrm{mM}$ thiosulfate were also present during the 1 -h incubation of injured $\mathrm{L} 10$ cells with $50 \mu \mathrm{M} \mathrm{FeSO}_{4}$, the activity of aconitase was restored to 87 and $94 \%$, respectively, of that in control L10 cells. Cysteine or 
thiosulfate induced some recovery of aconitase activity when added alone but we cannot exclude the possibility that this effect could be due to trace amounts of contaminating iron.

It is possible that further degradation of the iron-sulfur cluster occurs in injured target cells as the co-cultivation continues beyond 6-8 h. We were unable to reconstitute aconitase, complex I, and complex II activities by adding $50 \mu \mathrm{M} \mathrm{FeSO}$ and $1 \mathrm{mM}$ $\mathrm{L}$-cysteine to $\mathrm{L} 10$ cells (conditions described in the legend to Table VI) that had been co-cultivated with cytotoxic activated macrophages for $24 \mathrm{~h}$. Aconitase activity was measured polarographically as well as spectrophotometrically. Complex I and complex II activity was measured polarographically.

\section{Discussion}

We recently showed that $\mathrm{L} 10$ cells and $\mathrm{L} 1210$ cells co-cultivated with cytotoxic activated macrophages lose intracellular iron while remaining viable and growth inhibited (8). In the present study we show that loss of intracellular iron is associated with inhibition of the citric acid cycle enzyme aconitase and that the iron-sulfur prosthetic group of aconitase plays an essential role in the enzymatic inhibition. These results are the first evidence that mobilization of intracellular iron in target cells by a cytotoxic activated macrophage-mediated mechanism is causally related to inhibition of an enzyme with an iron-sulfur cluster.

When aconitase is isolated from cells it can be reversibly inactivated by mild oxidative conditions. Recent studies using Mössbauer spectroscopy showed that oxidative stress results in conversion of the [4Fe-4S] cluster of the active enzyme to a [3Fe-4S] cluster of the inactive enzyme by loss of an iron atom $(20,21,23)$. Upon incubation of the inactive enzyme in the presence of ferrous ion, or ferrous ion plus a reducing agent, the [3Fe-4S] cluster is converted to the active [ $4 \mathrm{Fe}-4 \mathrm{~S}$ ] cluster $(20$, $23,24)$. These results suggest ferrous ion is used to rebuild the active [4Fe-4S] cluster from the inactive [3Fe-4S] cluster.

The findings reported here have implications for iron-sulfur cluster interconversion in regulation of the in vivo catalytic activity of aconitase. Aconitase activity falls precipitously in L10 and L1210 target cells between 4 and $6 \mathrm{~h}$ of co-cultivation with cytotoxic activated macrophages and is undetectable by $8 \mathrm{~h}$ of co-cultivation. The loss of catalytic activity is not due to cytotoxic activated macrophage-induced inhibition of protein synthesis in L10 target cells. Rather than loss of or damage to the apoenzyme, the results observed are explained by cytotoxic activated macrophage induced removal of iron from the iron-sulfur prosthetic group of target cell aconitase. Dithionite, a reducing agent, largely prevents aconitase inhibition in L10 target cells. This is evidence that oxidative degradation of the $[4 \mathrm{Fe}-4 \mathrm{~S}]$ cluster correlates with aconitase inactivation. Furthermore, incubation of injured L10 cells with ferrous ion and thiosulfate or cysteine after $6.5 \mathrm{~h}$ of co-cultivation with cytotoxic activated macrophages causes virtual complete restoration of aconitase activity. These findings provide strong evidence that cytotoxic activated macrophage-induced inhibition of aconitase in L10 target cells is submolecular and mediated by iron removal from that enzyme's iron-sulfur center. The results are compatible with the possibility that aconitase, that has been inhibited in injured L10 cells by the activated macrophage cytotoxic mechanism, contains an inactive [3Fe-4S] cluster which is readily restored to an active [4Fe-4S] cluster by incorporation of a ferrous ion. Thus, the $[4 \mathrm{Fe}-4 \mathrm{~S}] \rightleftarrows[3 \mathrm{Fe}-4 \mathrm{~S}]$ interconversion of the cluster could represent a regulatory function for the iron-sulfur center of aconitase that is modulated by an activated macrophage mediated mechanism.

The kinetics of inhibition of complex I and complex II of the electron transport chain are slower than the kinetics of inhibition of aconitase activity. However, cytotoxic activated macrophage-mediated degradation of iron-sulfur clusters of complex I and complex II could explain the inhibition of their oxidoreductase activity and ultimately, inhibition of mitochondrial respiration. Complex I contains three [4Fe-4S] clusters (9). Whether or not redox-mediated interconversions of the $[4 \mathrm{Fe}-$ 4S] clusters in complex I occur is not known. Recent evidence shows that complex II contains a 3-iron cluster probably of the [3Fe-4S] type (25). The 3-iron cluster could arise by oxidative degradation of a [4Fe-4S] cluster in this enzyme complex. Therefore, both complex I and complex II, like aconitase, may contain [4Fe-4S] clusters and a similar mechanism could explain cytotoxic activated macrophage inhibition of their catalytic function.

The generalization that all enzymes containing iron-sulfur clusters are inhibited by the activated macrophage cytotoxic mechanism can not be made. Complex III of the mitochondrial electron transport system contains a [2Fe-2S] cluster that is essential for its electron transport function (9). Granger and Lehninger showed (7), and we confirmed in this study, that electron transfer can occur from ubiquinone through complex III to complex IV in mitochondria of injured target cells in which complex I and complex II are inhibited. However, because electron transport occurs at less than normal state 3 rates in both normal and injured target cells when $\alpha$-glycerol phosphate is the electron donor, partial inhibition of complex III in mitochondria of injured target cells would not have been detected with the experimental method used. It is of interest that a similar pattern of loss of bioenergetic function was observed in mitochondria from severely iron-deficient rats (26). The Fe-S clusters of complex I and complex II were markedly decreased while the Fe-S cluster of complex III was only minimally affected.

Endogenous respiration continues at a normal rate and exogenous $\alpha$-ketoglutarate is an effective respiratory substrate in injured L10 cells after $6 \mathrm{~h}$ of co-cultivation. At this time, aconitase activity is blocked but complex I and complex II are still functional. However, endogenous respiration is markedly inhibited after $22 \mathrm{~h}$ of co-cultivation, and NADH-linked substrates (including $\alpha$-ketoglutarate) as well as succinate are not effectively oxidized. This suggests that endogenous respiration measured after inhibition of aconitase activity, but before significant inhibition of complex I and complex II, could be due to oxidation of $\alpha$-ketoglutarate derived from the transamination of glutamate. It is also possible the malate-asparate shuttle or the $\alpha$-glycerol phosphate shuttle could transport reducing equivalents from extramitochondrial NADH into mitochondria and bypass aconitase block.

The kinetics of inhibition of aconitase activity in target cells of cytotoxic activated macrophages is exactly paralleled by the kinetics of inhibition of DNA synthesis as detected by $\left[{ }^{3} \mathrm{H}\right]$ thymidine uptake. Ribonucleotide reductase, the rate-limiting enzyme in DNA synthesis, contains non-heme iron essential for its catalytic activity (27). However, whether or not the mechanism of cytotoxic activated macrophage-mediated inhibition of DNA synthesis is similar to the mechanism of inhibition of aconitase activity is not known.

The biological significance of metabolic changes induced in target cells by cytotoxic activated macrophages has yet to be 
determined with certainty. These metabolic changes are selective and highly reproducible. It is possible that cytotoxic activated macrophage-mediated regulation of a pool of intracellular iron available for participation in catalytic function, particularly in enzymes with iron-sulfur prosthetic groups, could be a mechanism involved in control of cellular proliferation.

\section{Acknowledgments}

We are grateful to $R$. Christensen for assistance, and to G. Shaw, T. Childs, and $\mathrm{K}$. Welcker for typing the manuscript.

This work was supported by the Veterans Administration, Washington, DC. Dr. Drapier is an investigator of the Centre National de la Recherche Scientifique, France, and was supported by the Fogarty International Center, National Institutes of Health, Bethesda, MD, and the Philippe Foundation, New York.

\section{References}

1. Hibbs, J. B., Jr., L. H. Lambert, Jr., and J. S. Remington. 1972. Possible role of macrophage mediated nonspecific cytotoxicity in tumor resistance. Nature New Biol. 235:48-50.

2. Hibbs, J. B., Jr. 1973. Macrophage nonimmunologic recognition: Target cell factors related to contact inhibition. Science (Wash. DC). 180:868-870.

3. Meltzer, M. S., R. W. Tucker, and A. C. Breuer. 1975. Interaction of BCG-activated macrophages with neoplastic and nonneoplastic cell lines in vitro: cinemicrographic analysis. Cell Immunol. 17:30-42.

4. Ruco, L. P., and M. S. Meltzer. 1977. Macrophage activation for tumor cytotoxicity: induction of tumoricidal macrophages by supernatants of PPD-stimulated bacillus calmette-guerin-immune spleen cell cultures. J. Immunol. 119:889-896.

5. Pace, J. L., S. W. Russell, B. A. Torres, H. M. Johnson, and P. W. Gray. 1983. Recombinant mouse $\gamma$ interferon induces the priming step in macrophage activation for tumor cell killing. J. Immunol. 130: 2011-2013.

6. Granger, D. L., R. R. Taintor, J. L. Cook, and J. B. Hibbs, Jr. 1980. Injury of neoplastic cells by murine macrophages leads to inhibition of mitochondrial respiration. J. Clin. Invest. 65:357-370.

7. Granger, D. L., and A. L. Lehninger. 1982. Sites of inhibition of mitochondrial electron transport in macrophage-injured neoplastic cells. J. Cell Biol. 95:527-535.

8. Hibbs, J. B., Jr., R. R. Taintor, and Z. Vavrin. 1984. Iron depletion: possible cause of tumor cell cytotoxicity induced by activated macrophages. Biochem. Biophys. Res. Commun. 123:716-723.

9. Hatefi, Y. 1985. The mitochondrial electron transport and oxidative phosphorylation system. Ann. Rev. Biochem. 54:1015-1069.

10. Beinert, H., and A. J. Thomson. 1983. Three-iron clusters in iron-sulfur proteins. Arch. Biochem. Biophys. 222:333-361.

11. Kun, E., E. Kirsten, and W. N. Piper. 1979. [14] Stabilization of mitochondrial functions with digitonin. Methods Enzymol. 55:115118.

12. Hibbs, J. B., Jr., R. R. Taintor, H. A. Chapman Jr., and J. B. Weinberg. 1977. Macrophage tumor killing: influence of the local environment. Science (Wash. DC). 197:279-282.

13. Zuurendonk, P. F., and J. M. Tager. 1974. Rapid separation of particulate components and soluble cytoplasm of isolated rat-liver cells. Biochim. Biophys. Acta. 333:393-399.

14. Robinson, B. H., and J. B. Chappell. 1967. The inhibition of malate, tricarboxylate and oxglutarate entry into mitochondria by $2-n-$ butylmalonate. Biochem. Biophys. Res. Commun. 28:249-255.

15. Chappell, J. B. 1968. Systems used for the transport of substrates into mitochondria. Brit. Med. Bull. 24:150-157.

16. Davies, J. R., and R. K. Scopes. 1981. Purification of some tricarboxylic acid cycle enzymes from beef heart using affinity elution chromatography. Anal. Biochem. 114:19-27.

17. Henson, C. P., and W. W. Cleland. 1967. Purification and kinetic studies of beef liver cytoplasmic aconitase. J. Biol. Chem. 242:38333838.

18. Hibbs, J. B., Jr., and R. R. Taintor. 1986. Activated macrophage mediated cytotoxicity: use of in vitro cytotoxicity assay for study of bioenergetic and biochemical changes that develop in tumor target cells. Methods Enzymol. 136. In press.

19. Bradford, M. 1976. A rapid and sensitive method for the quantitation of microgram quantities of protein utilizing the principle of protein-dye binding. Anal. Biochem. 72:248-254.

20. Kennedy, M. C., M. H. Emptage, J. L. Dreyer, and H. Beinert. 1983. The role of iron in the activation-inactivation of aconitase. J. Biol. Chem. 258:11098-11105.

21. Kent, T. A., M. H. Emptage, H. Merkle, M. C. Kennedy, H. Beinert, and E. Münck. 1985. Mossbauer studies of aconitase. Substrate and inhibitor bindings, reaction intermediates, and hyperfine interactions of reduced 3Fe and 4Fe clusters. J. Biol. Chem. 260:6871-6881.

22. Dickman, S. R., and A. A. Cloutier. 1951. Factors affecting the activity of aconitase. J. Biol. Chem. 188:379-388.

23. Beinert, H., M. H. Emptage, J. L. Dreyer, R. A. Scott, J. E. Hahn, K. O. Hodgson, and A. J. Thomson. 1983. Iron-sulfur stoichiometry and structure of iron-sulfur clusters in three-iron proteins: evidence for [3Fe-4S] clusters. Proc. Natl. Acad. Sci. USA. 80:393-396.

24. Kent, T. A., J. L. Kreyer, M. C. Kennedy, B. H. Huynh, M. H. Emptage, H. Beinert, and E. Münck. 1982. Mossbauer studies of beef heart aconitase: evidence for facile interconversions of iron-sulfur clusters. Proc. Natl. Acad. Sci. USA. 79:1096-1100.

25. Ackrell, B. A. C., E. B. Kearney, W. B. Mims, J. Peisach, and H. Beinert. 1984. Iron-sulfur cluster 3 of beef heart succinate-ubiquinone oxidoreductase is a 3-iron cluster. J. Biol. Chem. 259:4015-4018.

26. Maguire, J. J., K. J. A. Davies, P. R. Dallman, and L. Packer. 1982. Effects of dietary iron deficiency on iron-sulfur proteins and bioenergetic functions of skeletal muscle mitochondria. Biochim. Biophys. Acta. 679:210-220.

27. Reichard, P., and A. Ehrenberg. 1983. Ribonucleotide reductaseA radical enzyme. Science (Wash. DC). 221:514-519. 